\title{
KONTROL STRUKTUR GEOLOGI PADA ALTERASI DAN MINERALISASI DI DAERAH CIBALIUNG, KABUPATEN PANDEGLANG, PROVINSI BANTEN
}

\section{CONTROL OF GEOLOGICAL STRUCTURE ON ALTERATION AND MINERALIZATION IN CIBALIUNG AREA, PANDEGLANG REGENCY, BANTEN PROVINCE}

\author{
Abdul Bari' ${ }^{1,2}$, Mega F Rosana1, dan Iyan Haryanto ${ }^{1}$ \\ ${ }^{1}$ Fakultas Teknik Geologi Universitas Padjadjaran, Bandung, Jawa Barat, Indonesia \\ ${ }^{2}$ PT Aneka Tambang Tbk., Jakarta \\ abdul.bari@antam.com
}

\begin{abstract}
ABSTRAK
Cibaliung terletak di dalam Honje Igneous Complex yang merupakan kompleks vulkanik berumur Miosen yang memiliki dua urat kuarsa yang ekonomis untuk ditambang yaitu urat Cikoneng dan urat Cibitung. Keterdapatan urat kuarsa di Cibaliung ini telah ditambang dan diproduksi oleh PT Cibaliung Sumber Daya anak perusahaan PT Aneka Tambang Tbk. Pada proses produksinya urat kuarsa ini telah mencapai batas maksimal produksinya sehingga diperlukan cadangan baru. Metodologi penelitian yang dilakukan antara lain pengamatan struktur geologi dengan analisis kelurusan topografi, circular feature, analisis kelurusan sungai melalui citra Digital Elevation Model, dan pengukuran struktur breksiasi, slickenside, shear fracture dan gash fracture. Hasil interpretasi data lapangan dari 328 lokasi pengamatan dengan 8.114 data struktur geologi menunjukkan bahwa keterdapatan struktur geologi berbanding lurus dengan intensitas alterasi dan mineralisasi. Dari hasil metode analisis struktur dan pergerakan sesar yang dikorelasikan dengan data mineralisasi dan alterasi didapatkan 14 daerah prospek yakni Prospek Cikoneng-Cibitung, Prospek Cibengang, Prospek Rorah Kadal, Prospek Cikeni, Prospek Ramada, Prospek Mastar, Prospek Muara Cikeni, Prospek Cipatat, Prospek Ciburial, Prospek Cikamancing, Prospek Sompok Uara, Prospek Batulawang Utara, Prospek Cikarae-Cingenge, dan Prospek Ciparay. Dari beberapa prospek tersebut direkomendasikan untuk dilakukan ekplorasi lebih lanjut pada enam prospek, yakni Prospek Cibengang, Prospek Ramada, Prospek Cikoneng Barat, Prospek Cikamancing, Prospek Sompok Utara dan Prospek Batulawang Utara.
\end{abstract}

Kata kunci: urat, struktur, alterasi, mineralisasi, prospek, Cibaliung

\section{ABSTRACT}

Cibaliung is located in the Honje Igneous Complex, which is a Miocene volcanic complex, having two economically mineable quartz veins, i.e. Cikoneng and Cibitung veins. These veins have been mined and produced by PT Cibaliung Sumber Daya - subsidiary of PT Aneka Tambang Tbk. In the production process, the veins have reached the maximum limit. Therefore, a new reserve must significantly be discovered. The research methodology includes observation of geological structures with topographic lineament analysis, circular feature, river lineament analysis using Digital Elevation Model, and measurement of brecciation structure, shear fracture and gash fracture. The results of field data interpretation from 328 observation locations with 8,114 geological structure data both for shear fracture and gash fracture show that the presence of geological structures is directly proportional to the intensity of alteration and mineralization. From the structural and fault movement analysis and the correlation with mineralization and alteration data, there can be delineated 14 prospect areas, namely the Cikoneng-Cibitung, Cibengang, Rorah Kadal, Cikeni, Ramada, Mastar, Muara Cikeni, Cipatat, Ciburial, Cikamancing, Sompok Uara, North Batulawang, Cikarae-Cingenge, and Ciparay Prospects. From these prospects, it is recommended to 


\section{MAKALAH ILMIAH}

conduct further exploration on six prospects, namely Cibengang, Ramada, West Cikoneng, Cikamancing, North Sompok and the North Batulawang Prospects.

Keywords: vein, structure, alteration, mineralization, prospect, Cibaliung

\section{PENDAHULUAN}

Daerah Banten Selatan khususnya Cibaliung terletak di pusat dari bagian busur magmatik Neogen Sunda-Banda (Carlile dan Mitchell, 1994). Busur SundaBanda ini merupakan busur yang paling panjang di Indonesia yang membentang dari Sumatra-Jawa-Nusa Tenggara-hingga Maluku. Daerah ini juga berada di zona transisi dari sesar geser yang berorientasi baratlaut - tenggara di Sumatra (Angeles dkk, 2002) yang memanjang sampai ke batas Palung Sunda dalam bentuk suatu sistim graben (Handayani dan Harjono, 2008).

Cibaliung merupakan wilayah gunung api purba berumur Miosen yang terbentuk karena subduksi lempeng Indo-Australia ke arah timurlaut (Atmadja dan Noeradi, 2005). Daerah ini memiliki endapan mineral berupa urat kuarsa ekonomis yaitu Urat Cikoneng dan Urat Cibitung yang telah ditambang dan diproduksi oleh PT Cibaliung Sumber Daya anak perusahaan PT Aneka Tambang Tbk sejak tahun 2009. Pada proses produksinya urat kuarsa ini telah mencapai batas maksimal produksinya sehingga diperlukan cadangan baru di sekitar area tambang.

Mineralisasi di daerah Cibaliung termasuk tipe sulfidasi rendah. Kehadiran emas pada sistim ini berada pada urat sebagai tempat terakumulasinya unsur berharga tersebut. Keterdapatan urat sendiri disebabkan adanya zona bukaan yang muncul akibat proses deformasi yang diisi oleh fluida hidrotermal. Oleh karena itu perlu dilakukan studi untuk mengetahui zona bukaan yang terisi oleh fluida hidrotermal dalam batuan pembawa mineralisasi.

Lokasi penelitian berada di wilayah Izin Usaha Pertambangan (IUP) PT Aneka Tambang Tbk (Antam) dan PT Cibaliung
Sumber Daya (CSD) dan secara administratif terletak di Kecamatan Cimanggu-Cibitung, Kabupaten Pandeglang, Provinsi Banten (Gambar 1).
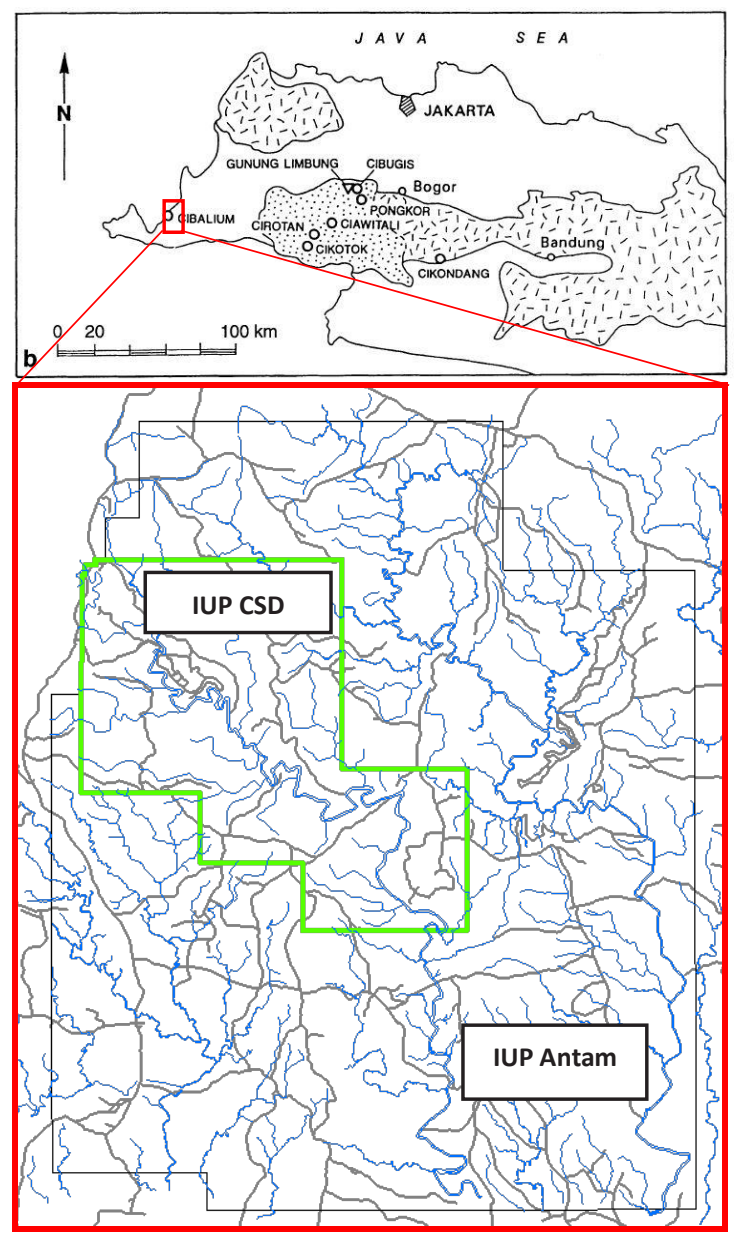

Gambar 1. Peta lokasi penelitian (modifikasi Marcoux dan Milesi, 1994)

Daerah penelitian terletak di dalam Honje Igneous Complex dan Formasi Bojongmanik yang berada di atas Formasi Cimapag yang memiliki hubungan menjemari dan berumur Miosen Tengah Pliosen. Formasi Honje diendapkan pada lingkungan darat yang diketahui berdasarkan kehadiran fosil kayu terkersikkan sementara Formasi Bojongmanik diendapkan pada lingkungan darat sampai laut dangkal (Sudana dan Sentosa, 1992). 
Penelitian ini dilakukan untuk menentukan hubungan keterdapatan urat kuarsa dengan struktur yang berkembang, mengidentifikasi jalur utama mineralisasi dan kemungkinan jalur-jalur lain dengan tujuan untuk memberikan saran eksplorasi berikutnya.

\section{GEOLOGI REGIONAL}

Berdasarkan Peta Geologi Lembar Cikarang (Sudana dan Santosa, 1992) batuan yang tersingkap berumur Miosen Tengah hingga Pliosen, terdiri dari batuan sedimen, batuan gunungapi dan batuan terobosan. Satuan batuan tertua ditempati Formasi Cimapag berumur Miosen Akhir dengan litologi terdiri atas beberapa batuan mulai dari yang tua ke muda adalah breksi, lava andesit terpropilitkan, batupasir, batulempung, batugamping, konglomerat, tuf dan aglomerat. Sedangkan yang paling muda pada formasi ini terdiri atas tuf dasitik, lava andesit dan breksi tuf. Di atas Formasi Cimapag diendapkan Formasi Bojongmanik dan Formasi Honje (Gambar 2) secara tidak selaras yang didominasi oleh lava andesit dan tuf (Usman, D.N. et al., 2018) serta diterobos oleh andesit basalt (Sudana dan Santosa, 1992. Menurut Kurniawan dkk (2012), litologi di wilayah penelitian didominasi batuan vulkanik berupa andesit, andesit porfiritik, tuf, breksi volkanik dan breksi polimik yang pada batuan volkanik di bagian tenggara ditutupi oleh satuan batugamping (Gambar 3).

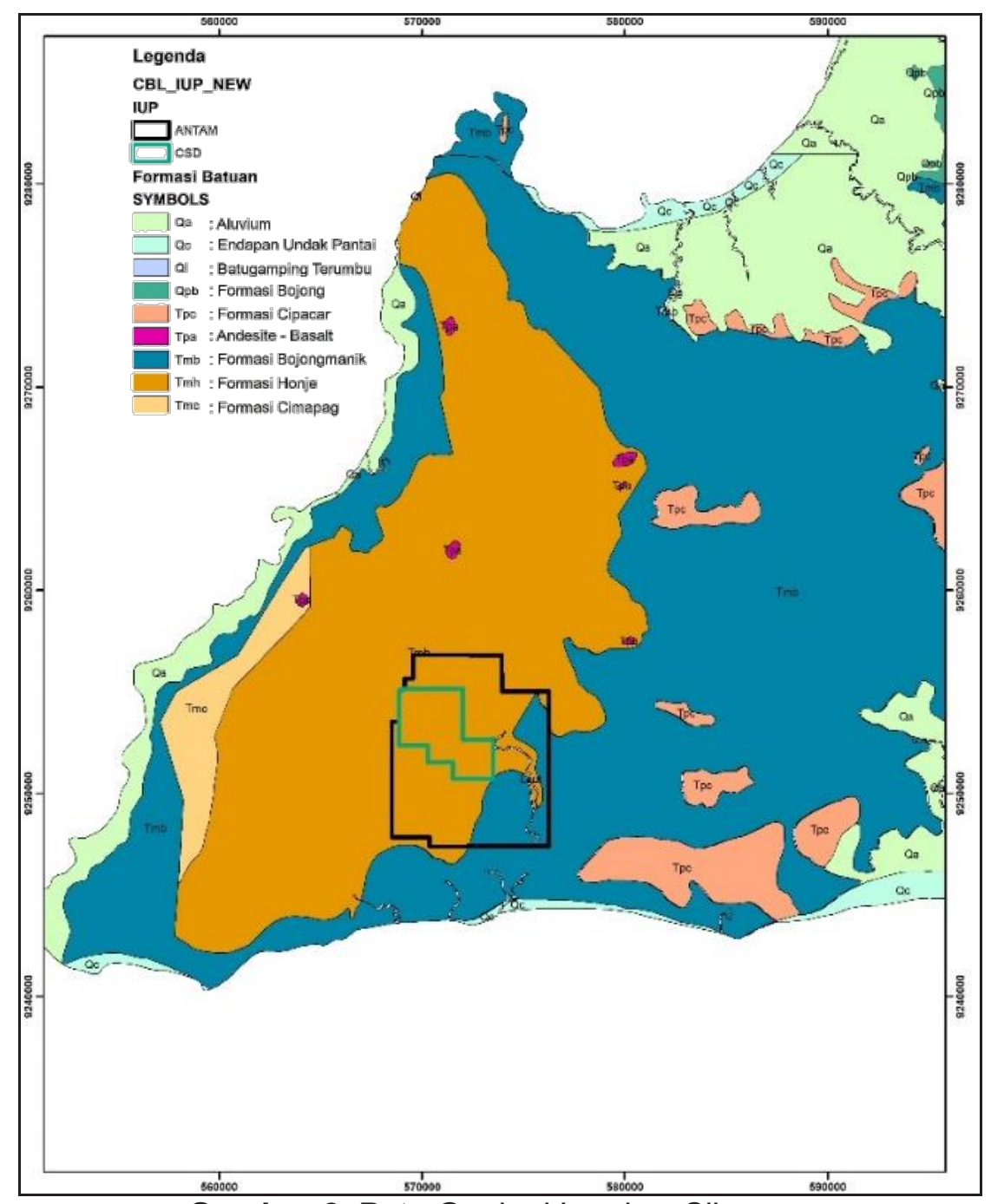

Gambar 2. Peta Geologi Lembar Cikarang

(dimodifikasi dari Sudana dan Santosa, 1992) 


\section{MAKALAH ILMIAH}

Mineralisasi di daerah Cibaliung diidentifikasi dengan kehadiran tipe urat sistim sulfidasi rendah pada Urat Cikoneng-Cibitung yang telah ditambang dan diproduksi oleh PT Cibaliung Sumber

Daya anak perusahaan PT Antam (Gambar 4) dengan arah struktur dominan baratlaut-tenggara (Usman, D.N. et al., 2017) mengikuti pola Sumatra (Hilmi dan Haryanto, 2008)

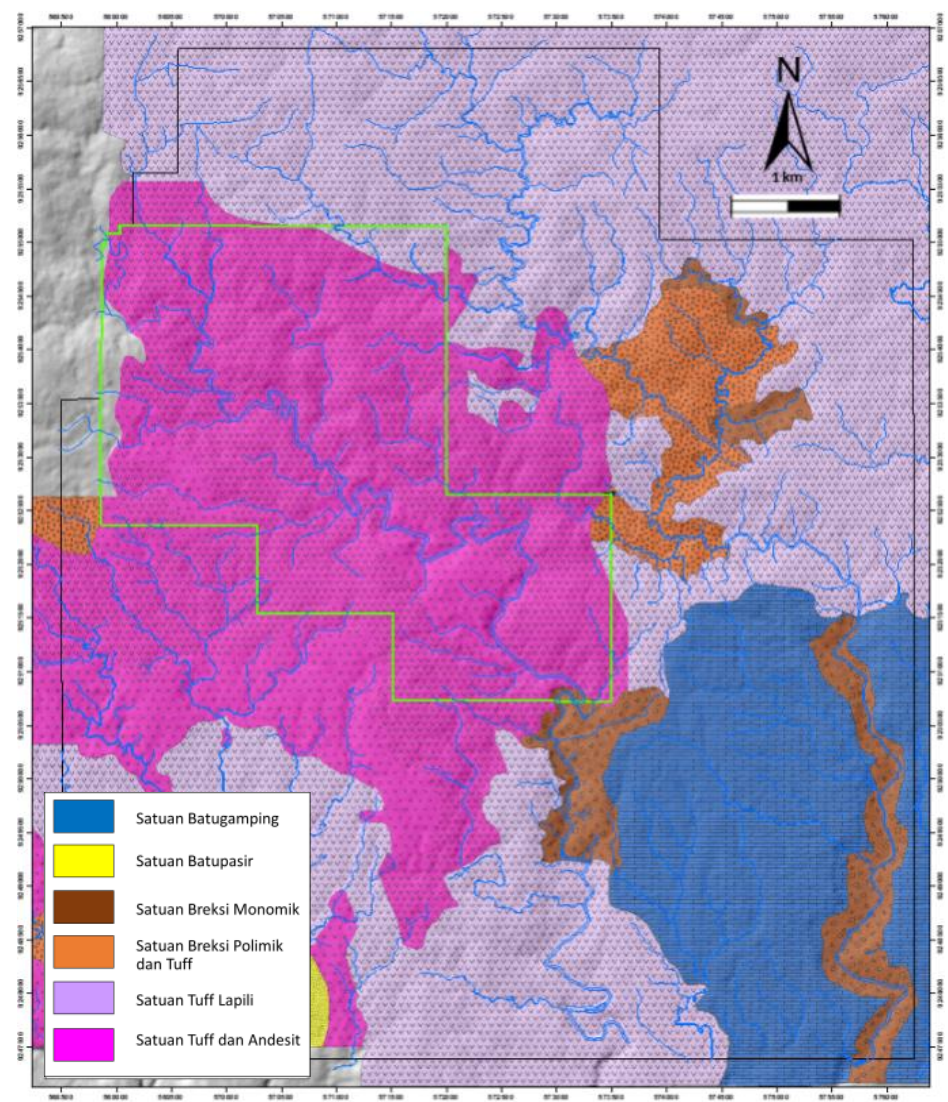

Gambar 3. Peta geologi IUP PT. CSD dan Antam (Kurniawan dkk., 2012)
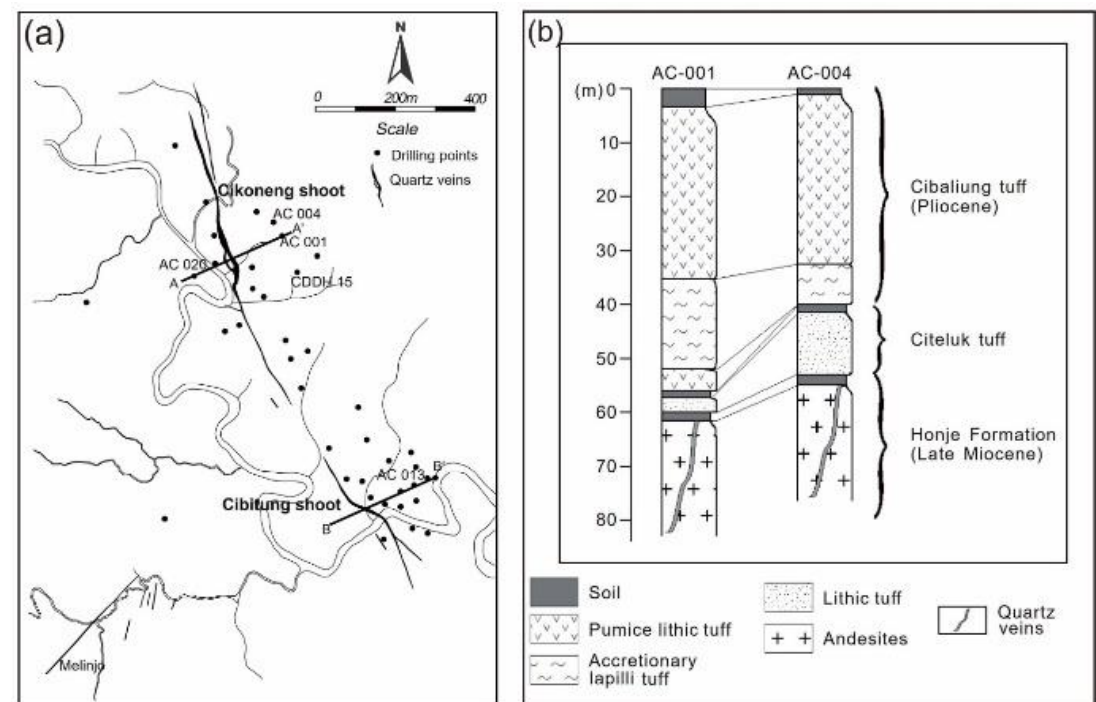

Gambar 4. (a) Peta lokasi Cikoneng dan Cibitung shoot, (b) stratigrafi lokal endapan Cibaliung mulai dari Formasi Honje, Tuf Citeluk, dan Tuf Cibaliung (dimodifikasi dari Harijoko dkk., 2004) 


\section{METODE PENELITIAN}

Dalam studi ini, pengambilan data primer dilakukan dengan metode pemetaan dengan skala 1: 5.000 dan pengamatan struktur dengan analisis kelurusan topografi, circular feature, analisis kelurusan sungai melalui citra Digital Elevation Model (DEM), pengambilan data breksiasi, slickenside, shear fracture dan gash fracture (Gambar 5 dan Gambar 6).

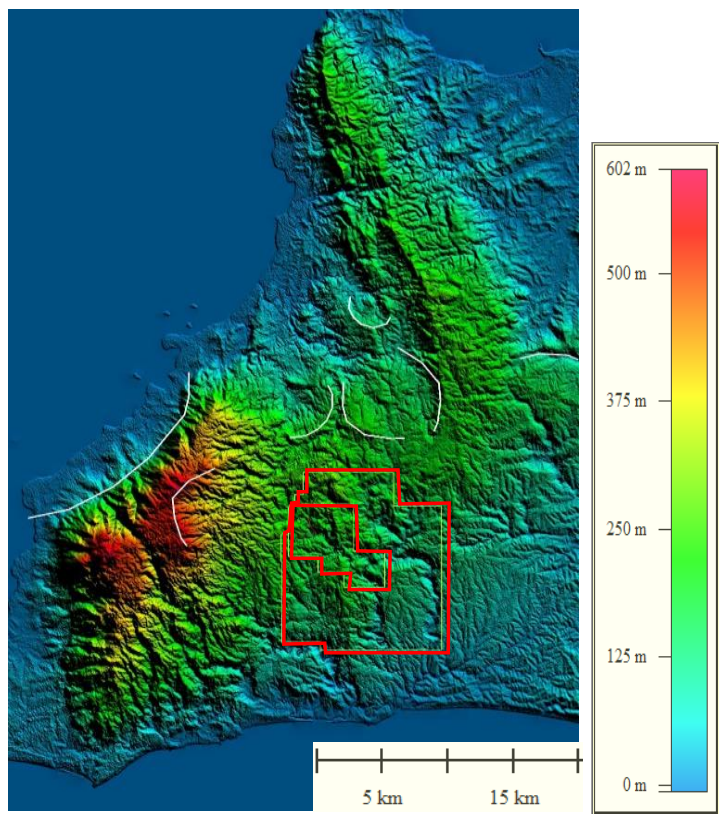

Gambar 5. Peta DEM penarikan kenampakan circular feature

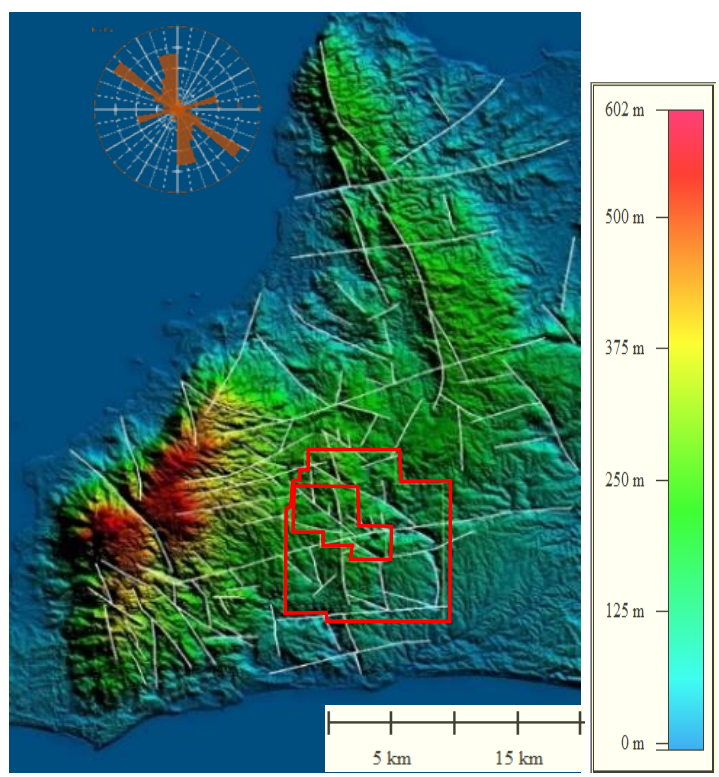

Gambar 6. Peta DEM penarikan kenampakan kelurusan morfologi

\section{HASIL DAN PEMBAHASAN}

Hasil pengambilan data struktur di Cibaliung yang berada di sekitar IUP PT CSD dan IUP PT Antam sebanyak 8.114 data dirangkum dalam Tabel 1.

Tabel 1. Data struktur geologi

\begin{tabular}{ll}
\hline \multicolumn{2}{c}{ Statistik Dasar } \\
\hline Total Stasiun & 328 stasiun \\
\hline Jarak Antar Stasiun & $20-100 \mathrm{~m}$ \\
\hline Total Shear fracture & 7.547 data \\
\hline Total Gash fracture & 567 data \\
\hline Total Data Struktur & 8.114 data \\
\hline
\end{tabular}

Rata-rata pengambilan data shear fracture dan gash fracture tiap stasiun sebanyak 24 data. Hal tersebut menunjukkan data yang cukup valid. Data struktur yang kurang dari 20 data tetap dilakukan penarikan namun perlu ditandai. Kekurangan data pada stasiun tersebut disebabkan oleh faktor pelapukan dan jenis batuan seperti breksi, tuf, atau andesit teralterasi kuat sehingga cukup sulit untuk dilakukan pengamatan. Pengambilan data struktur dibagi menjadi 4 blad yaitu A1, A2, B1, dan B2 (Gambar 7).

Blad A1 dominan berada di wilayah IUP CSD sementara blad A2, B1, dan B2 dominan berada di wilayah IUP PT Antam. Dari observasi lapangan didapatkan hasil pergerakan pada tiap sesar melalui metode analisis struktur dengan menggunakan diagram roset. Data shear fracture dan gash fracture diolah dengan menggunakan software stereonet. Pada satu stasiun data shear fracture dikumpulkan lalu dibuat menjadi polar. Polar-polar tersebut dilakukan contouring dan menghasilkan beberapa pola shear dominan. Shear dominan tersebut merupakan indikasi adanya pergerakan dominan dengan orientasi searah shear tersebut. 


\section{MAKALAH ILMIAH}

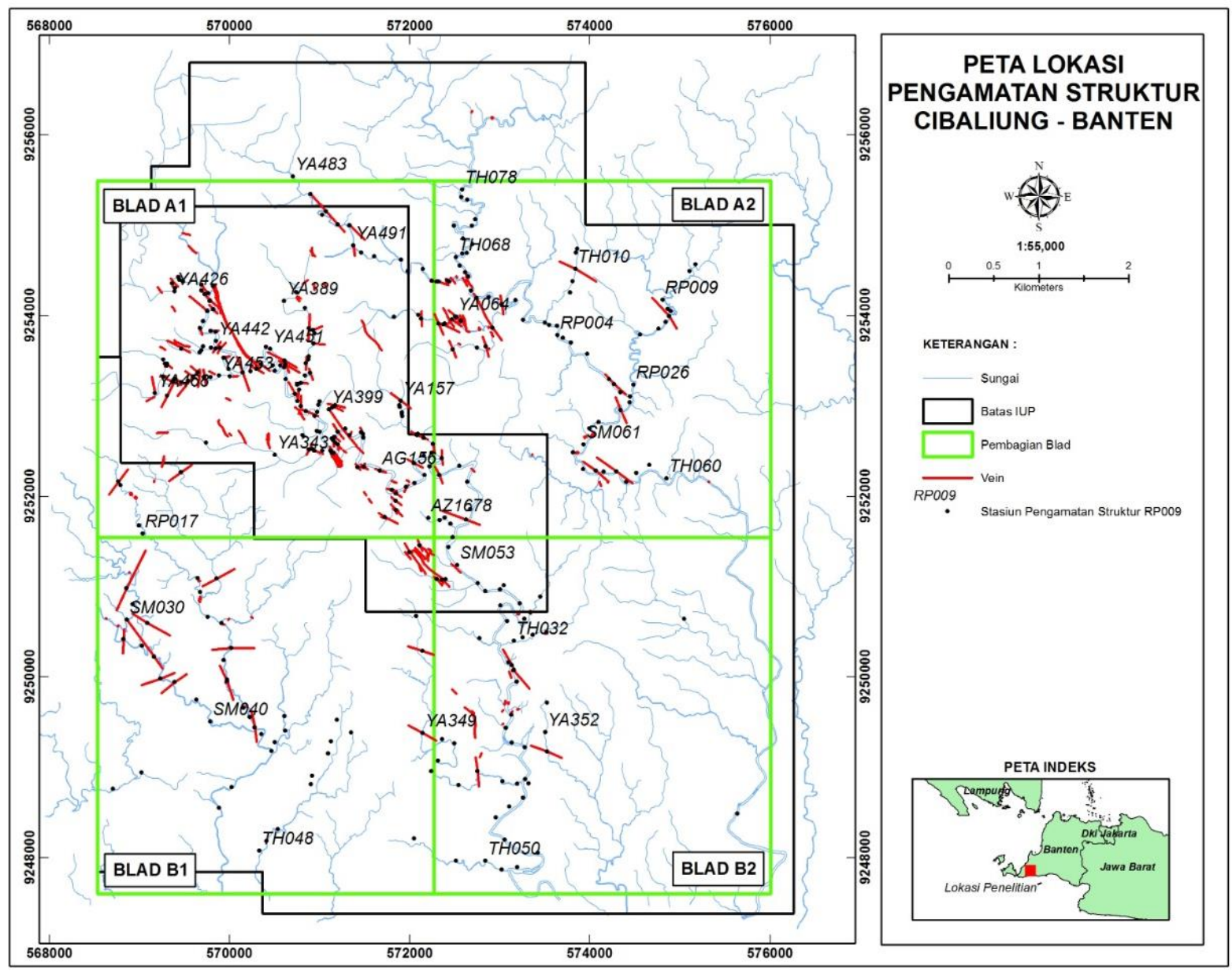

Gambar 7. Peta lokasi pengamatan struktur Cibaliung

Data shear fracture dan gash fracture pada tiap stasiun di analisis untuk mengetahui pergerakan sesar menggunakan model Harding (1980) berdasarkan hubungan struktur penyerta dengan sesar utamanya, arah pergerakan sesar akan menuju sudut lancip dari gash fracture. Jika tidak terdapat gash fracture maka pergerakan didekati dengan $\delta 2$ yang merupakan titik perpotongan 2 shear dengan asumsi dalam kondisi satu tegasan (Gambar 8). Setelah itu dihasilkan beberapa analisis pergerakan pada setiap sesar yang ada di daerah penelitian. Hasil tersebut antara lain Sesar Major A1, Sesar Major A2, Sesar Sintetik A (orde 1), Sesar Sintetik A (orde 2), Sesar Major B, Sesar Sintetik B (orde 1), dan post mineralization fault.

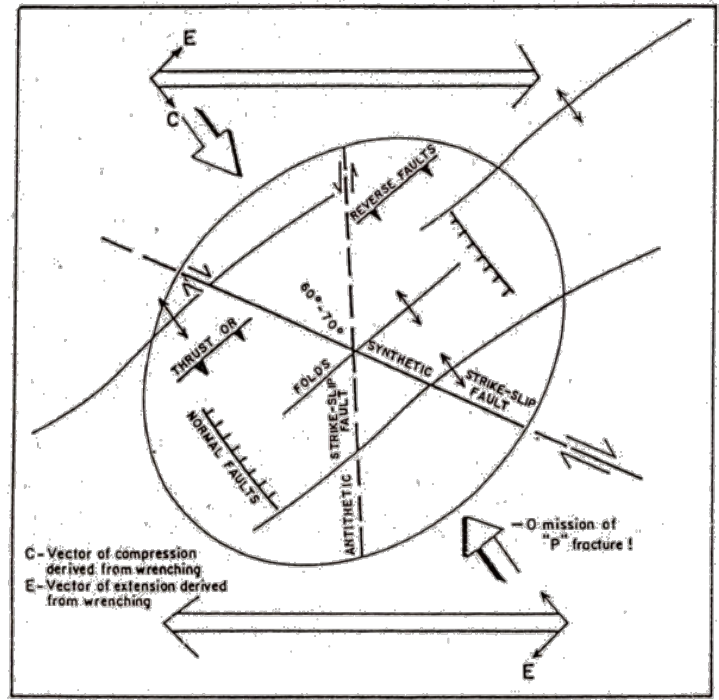

Gambar 8. Model simple shear (Harding, 1980) 

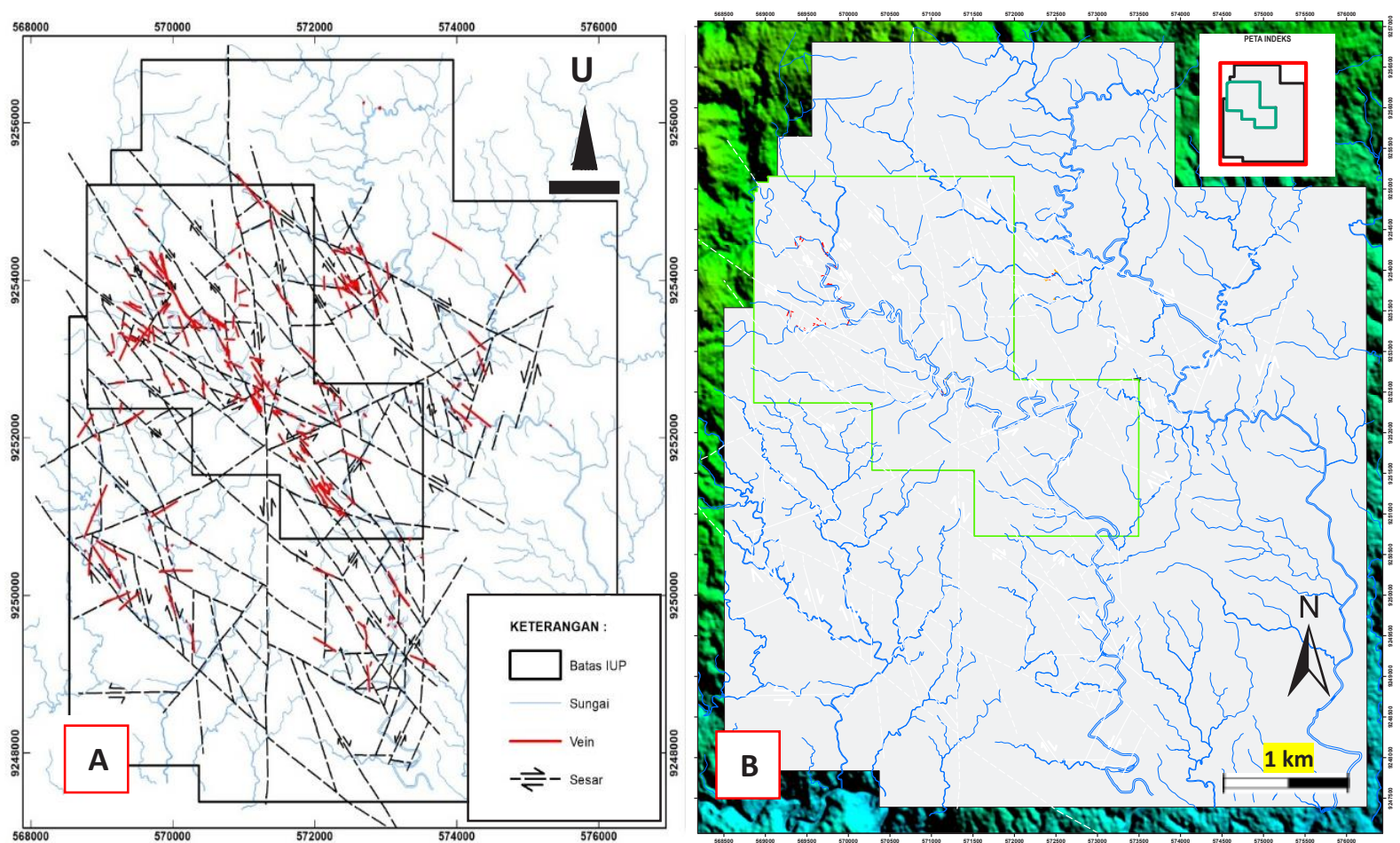

Gambar 9. (A) Peta struktur dari analisis kinematik dan dinamik serta kelurusan data DEM

(B) Peta struktur overlay dengan data DEM

Berdasarkan hasil analisis kinematik dan dinamik, dihasilkan peta struktur geologi (Gambar 9). Pembentukan sesar diawali dengan Sesar Major A1 dan Sesar Major A2 dengan pergerakan menganan. Sesar Major A1 memiliki kedudukan $\mathrm{N} 103^{\circ} \mathrm{E} / 88^{\circ} \mathrm{NE}$, pitch $16^{\circ}$, dengan pergerakan menganan didapatkan tegasan $\delta 1=12.7^{\circ}, \mathrm{N} 328^{\circ} \mathrm{E}, \quad \mathrm{\rho} 3=10^{\circ}$, $\mathrm{N} 236^{\circ} \mathrm{E}$ (Gambar 10). Sementara Sesar Major A2 memiliki kedudukan $\mathrm{N} 114^{\circ} \mathrm{E} / 84^{\circ} \mathrm{NE}$, pitch $8^{\circ}$, dengan pergerakan menganan, didapatkan tegasan $\delta 1=10^{\circ}, \mathrm{N} 338^{\circ} \mathrm{E} ; \mathrm{Q} 3=1^{\circ}, \mathrm{N} 248^{\circ} \mathrm{E}$ (Gambar 11).

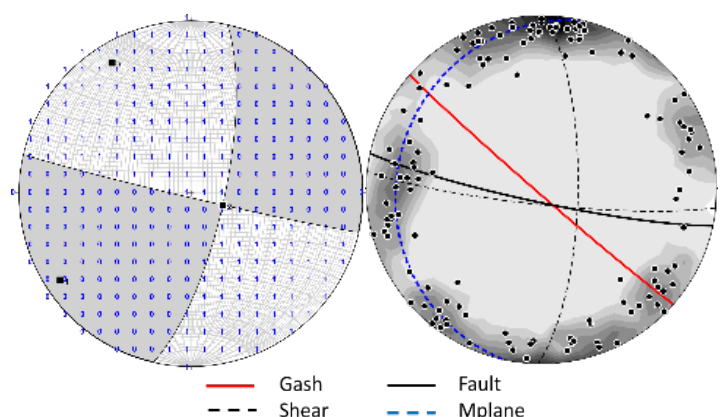

Gambar 10. Analisis kinematik sesar major A1

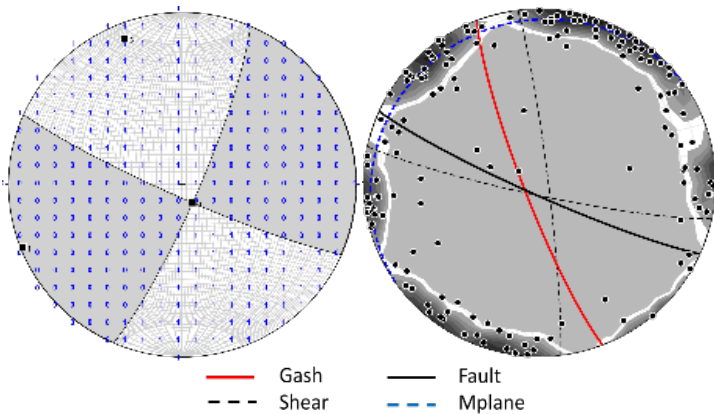

Gambar 11. Analisis kinematik sesar major A2

Pergerakan menganan tersebut menghasilkan objek di antara dua sesar mengalami proses coaxial sehingga menghadirkan sistim simple shear serta bukaan-bukaan di dalamnya yang menjadi isian fluida hidrotermal/mineralisasi. Bukaan-bukaan tersebut hadir menjadi Sesar Sintetik A (orde 1) dengan hasil dari analisis kinematiknya adalah sesar utama dengan kedudukan $\mathrm{N} 158^{\circ} \mathrm{E} / 83^{\circ} \mathrm{NE}$, pitch $12^{\circ}$, dengan pergerakan menganan dan tegasan $\delta 1=3^{\circ}, \mathrm{N} 204^{\circ} \mathrm{E}$; $\mathrm{\rho} 3=13^{\circ}, \mathrm{N} 113^{\circ} \mathrm{E}$ (Gambar 12). 


\section{MAKALAH ILMIAH}

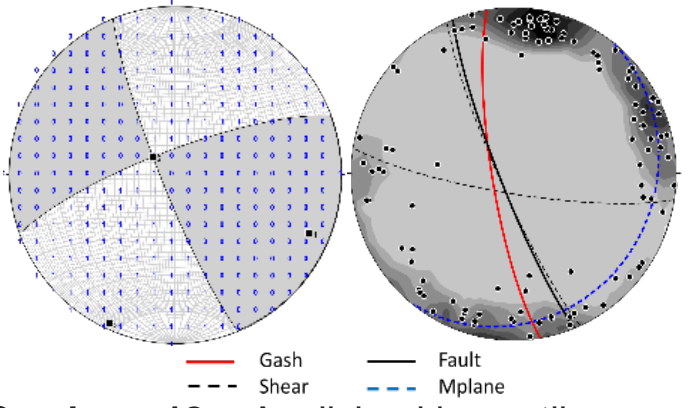

Gambar 12. Analisis kinematik sesar sintetik A (Orde 1)

Seiring berjalannya waktu proses deformasi yang semakin intensif akan membentuk Sesar Antitetik A (orde 2) yang terbentuk diantara Sesar Sintetik (orde 1) dan dapat menjadi bukaan namun dengan ukuran yang lebih kecil. Bersama dengan sesar-sesar antitetik mungkin juga dapat terbentuk sesar-sesar minor yang lebih kecil. Sesar Antitetik A (orde 2) tesebut memiliki analisis kinematik berupa sesar utama dengan kedudukan $\mathrm{N} 158^{\circ} \mathrm{E} / 83^{\circ} \mathrm{NE}$, pitch $12^{\circ}$, dengan pergerakan menganan dan nilai tegasan $\delta 1=15^{\circ}, \quad \mathrm{N} 004^{\circ} \mathrm{E} ; \quad \mathrm{\rho} 3=4^{\circ}, \quad \mathrm{N} 273^{\circ} \mathrm{E}$. (Gambar 13).

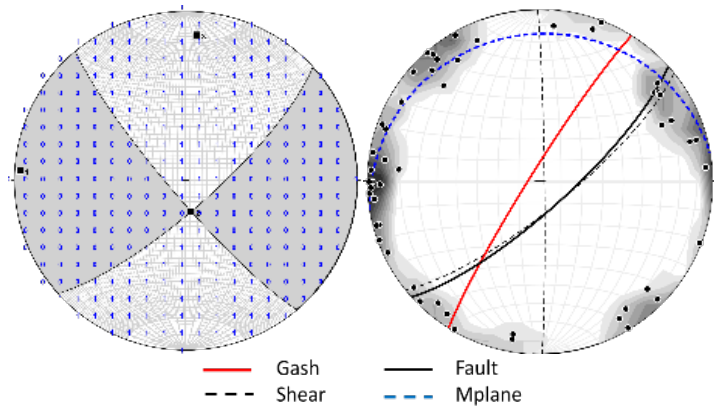

Gambar 13. Analisis kinematik sesar antitetik A (Orde 2)

Setelah pembentukan Sesar Major A1 dan Sesar Major A2, Terdapat juga sesar dengan orientasi NE-SW yang memotong kedua sesar, Sesar Major A1 dan Sesar Major A2. Fase pembentukan sesar ini kemungkinan masih dalam proses aktifnya fluida hidrotermal sehingga pada sesar ini masih ada kecenderungan alterasi yang cukup intensif pada zona perpotongan bukaan Sesar Major B dengan Sesar Major A1. Hasil dari analisis kinematik dari Sesar Major B ini berupa sesar utama dengan kedudukan $\mathrm{N} 257^{\circ} \mathrm{E} / 82^{\circ} \mathrm{NE}$, pitch $06^{\circ}$, dengan pergerakan mengiri dan nilai tegasan $\delta 1=10^{\circ}, \mathrm{N} 212^{\circ} \mathrm{E} ; \mathrm{\rho} 3=1^{\circ}, \mathrm{N} 122^{\circ} \mathrm{E}$ (Gambar 14).

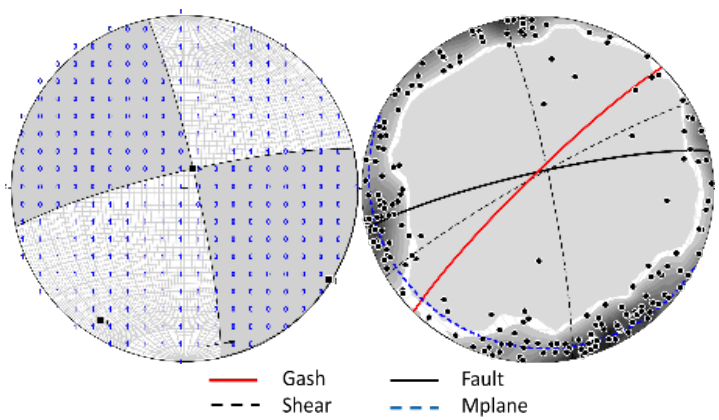

Gambar 14. Analisis kinematik sesar major B

Sesar Major B ini juga membentuk Sesar Sintetik B (orde 1) sebagai bukaan terhadap sesar ini. Dengan hasil dari analisis kinematik berupa sesar utama dengan kedudukan $\mathrm{N} 220^{\circ} \mathrm{E} / 85^{\circ} \mathrm{NE}$, pitch $19^{\circ}$, dengan pergerakan mengiri dan nilai tegasan $\delta 1=10^{\circ}, \mathrm{N} 352^{\circ} \mathrm{E}$; $\mathrm{\rho} 3=17^{\circ}, \mathrm{N} 86^{\circ} \mathrm{E}$ (Gambar 15).

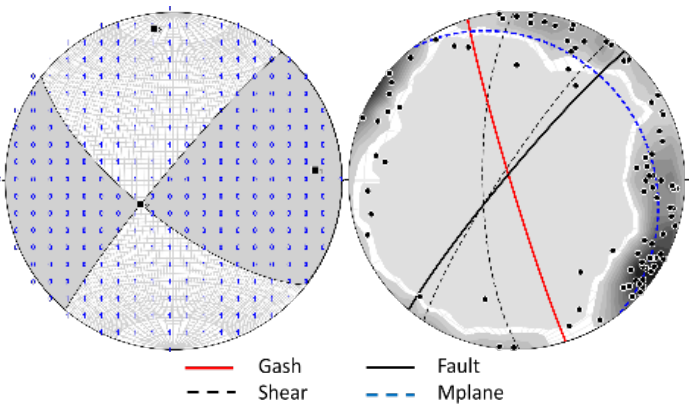

Gambar 15. Analisis kinematik sesar sintetik B (Orde 1)

Pada fase setelah mineralisasi terbentuklah sesar dengan trend relatif utara-selatan yang memotong Sesar Major A1, Sesar Major A2 dan sekitar Sesar Major B. Karena jarangnya alterasi yang hadir di sekitar sesar ini diintepretasikan bahwa sesar ini terbentuk paling akhir (post mineralization fault). Hasil dari analisis kinematik pada sesar ini adalah sesar utama dengan kedudukan $\mathrm{N} 355^{\circ} \mathrm{E} / 87^{\circ} \mathrm{NE}$, pitch $22^{\circ}$, dengan pergerakan menganan. Tegasan yang didapatkan adalah $\delta 1=13^{\circ}, \quad \mathrm{N} 42^{\circ} \mathrm{E}$; ९3 $=18^{\circ}$, N308 ${ }^{\circ}$ E. (Gambar 16). 


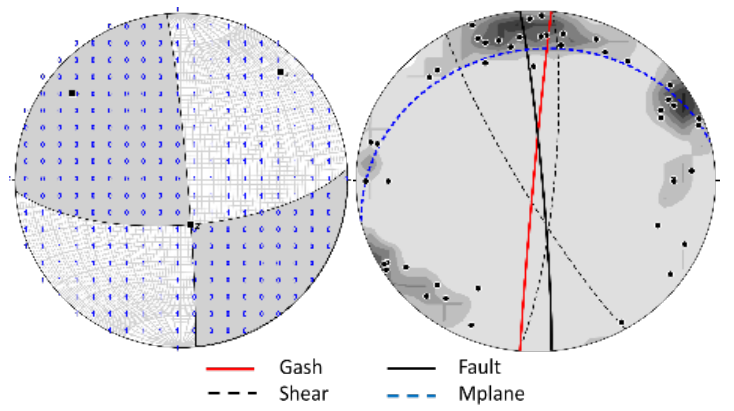

Gambar 16. Analisis kinematik sesar post mineralization fault

Hubungan antar sesar-sesar tersebut digambarkan pada peta struktur geologi (Gambar 17). Kemudian untuk mengetahui korelasi antara struktur dengan alterasi, dilakukan tumpang susun (overlay) peta struktur terhadap peta alterasi. Pola alterasi dominan (Gambar 18) berada diantara dua sesar, yaitu Sesar Major A1 dan Sesar Major A2 (garis merah muda). Sedangkan orientasi pola alterasi illitic menunjukan orientasi yang sama dengan arah struktur NW-SE yang merupakan pola sesar sintetik (orde 1) yang digambarkan dengan (garis putus-putus merah). Setempat juga hadir pola alterasi yang sama dengan orientasi sesar antitetik (orde 2). Semakin jauh ke arah timur intensitas keasaman dari fluida hidrotermal umumnya semakin berkurang. Hal tersebut disebabkan karena semakin jauhnya dari pusat sumber panas yang diintepretasi berada di bagian barat (Gambar 19).

Pola keasaman alterasi pada bagian tenggara daerah penelitian semakin meningkat. Terjadinya hal yang demikian diintepretasikan akibat dari zona bukaan Sesar Major B yang bertemu dengan Sesar Major A1 yang menimbulkan proses alterasi yang lebih intensif dan dapat memicu proses intrusif yang membawa fluida magmatik sehingga alterasi cenderung berubah relatif lebih asam (Gambar 20).

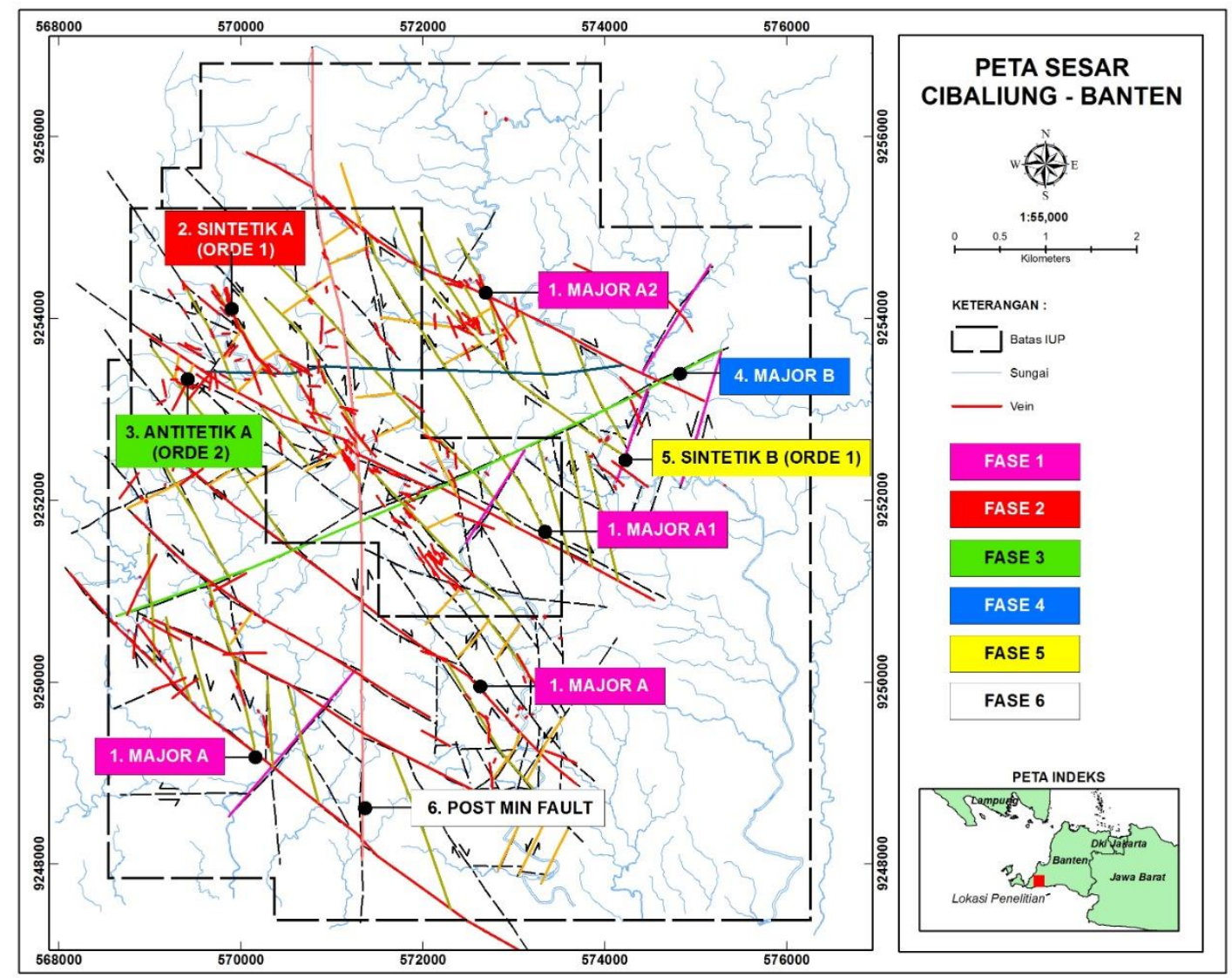

Gambar 17. Peta struktur geologi Cibaliung 


\section{MAKALAH ILMIAH}

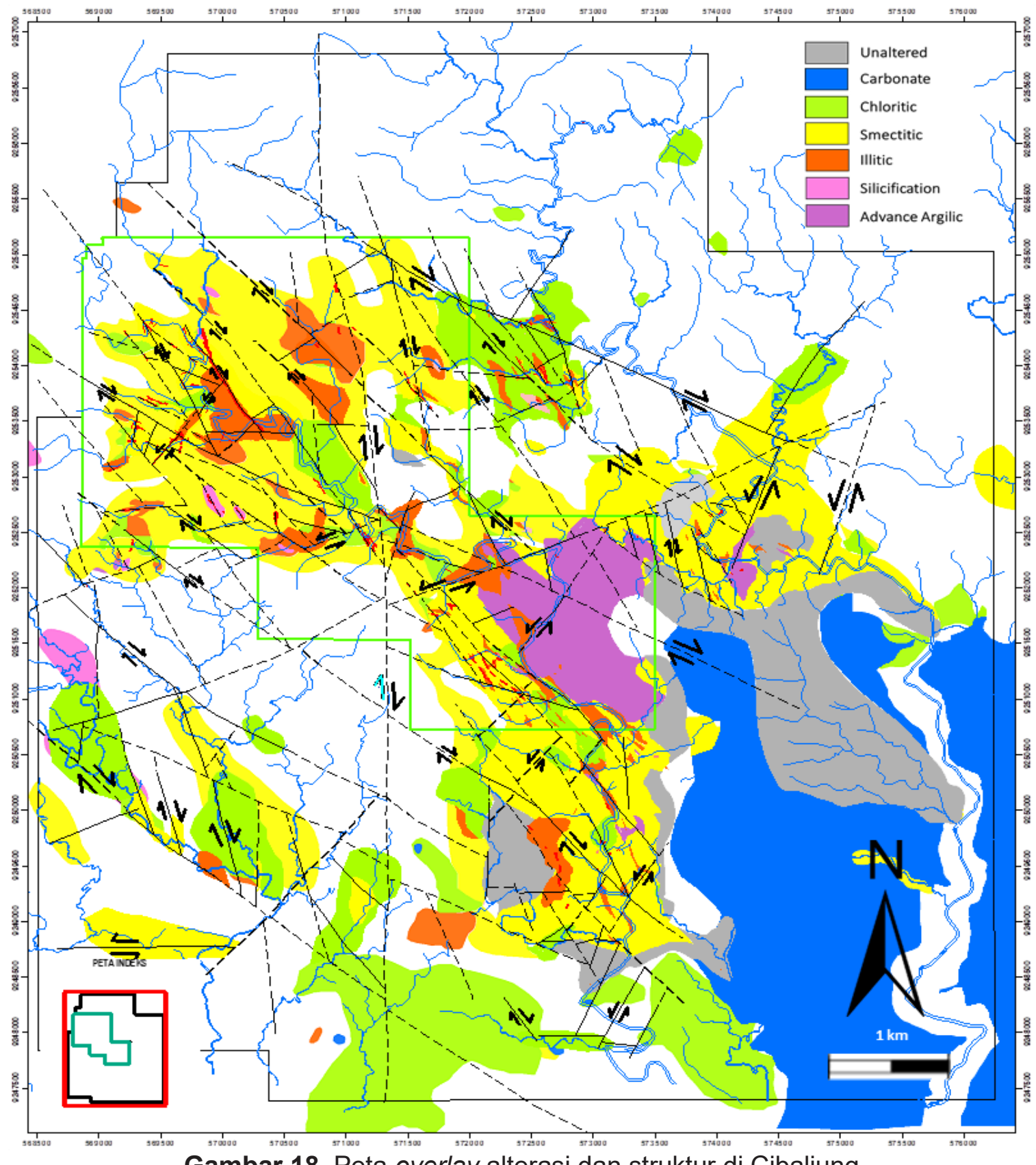

Gambar 18. Peta overlay alterasi dan struktur di Cibaliung

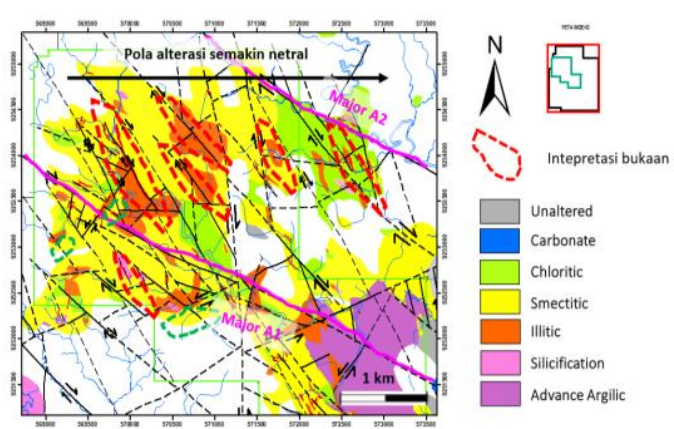

Gambar 19. Ilustrasi bukaan dari struktur pada sintetik yang didukung pola alterasi

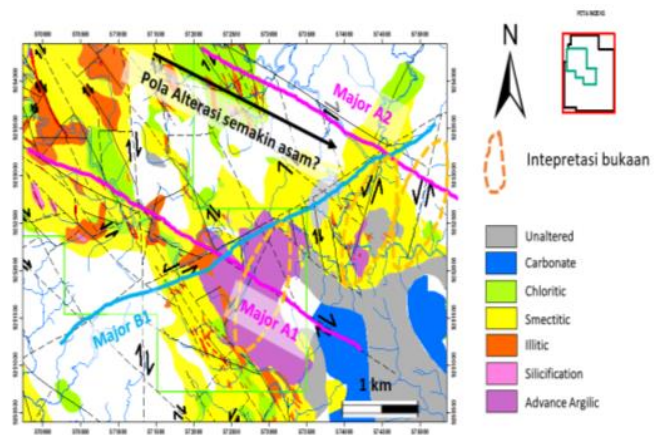

Gambar 20. Illustrasi bukaan dari struktur pada sintetik (Orde 1) yang didukung pola alterasi 
Untuk mineralisasi yang terjadi di daerah penelitian didominasi oleh tipe urat epitermal sistim sulfidasi rendah. Sistim ini dicirikan dengan kehadiran alterasi berupa mineral netral seperti ilit, serisit, dan adularia (Hedenquist, 1996). Keterdapatan bijih pada sistim epitermal sulfidasi rendah umumnya dalam bentuk urat kuarsa dengan mineralisasi Ag-sulfide berupa achantite atau argentite dengan tekstur mengisi rongga dan keterdapatan stockwork yang cukup dominan.

Hasil analisis pengaruh struktur terhadap mineralisasi berdasarkan analisis pergerakan sesar dan metode shear zone boundary berdasarkan McClay (1987) didapatkan beberapa prospek yang dibagi menjadi Prospek Cikoneng-Cibitung, Prospek Cibeber, Prospek Rorah Kadal dan Cikeni, dan Ramada, Prospek Mastar, Muara Cikeni, dan Nira, Prospek Cipatat, Prospek Ciburial, Prospek CikaraeCingengedan Prospek Ciparay.

Berdasarkan hasil dari analisis struktur dan didukung dengan data lainnya, keterdapatan urat kuarsa sebagai wadah mineralisasi umumnya hadir pada Sesar Sintetik A (orde 1), setempat juga hadir mengisi Sesar Antitetik A (orde 2) namun hanya di sekitar Prospek Cibeber. Hal tersebut kemungkinan dipengaruhi oleh tekanan dari fluida hidrotermal yang menambah daya buka terutama pada posisi dekat dengan sumber panas yang diintepretasikan sendiri berada di barat IUP PT CSD dan IUP PT Antam. Keterdapatan urat umumnya hadir di daerah sekitar Sesar Major A1 dan Sesar Major A2 yang berada di IUP PT CSD.
Pada IUP Antam pola alterasi yang cenderung asam, dikontrol oleh Sesar Major B. Sesar tersebut merupakan sesar yang memotong Sesar Major A1 dan Sesar Major A2. Pada daerah perpotongan umumnya akan hadir alterasi dengan intensitas lebih asam. Hal tersebut diintepretasikan bahwa pertemuan sesar menghasilkan bukaan yang memicu naiknya intrusi yang membawa fluida magmatik sehingga dapat membuat salinitas dan keasaman yang meningkat. Pada bagian selatan bukit breksi terdapat mekanisme deformasi yang memiliki banyak conjugate namun masih belum ditemukan urat dengan ukuran yang signifikan. Di daerah Ciparay juga terdapat float-float dengan kadar emas berkisar dari 4,16 ppm hingga 8,28 ppm namun belum diketahui asal sumbernya.

Hasil analisis struktur dan alterasi kemudian ditambah dengan data geofisika groundmagnet first horizontal derivative untuk menentukan strategi eksplorasi ke depannya. Rekomendasi target eksplorasi didasarkan pada kombinasi hasil interpretasi berupa zona bukaan yang didukung oleh data alterasi dan data geofisika groundmagnet berupa first horizontal derivative.

Zona bukaan yang dimaksud adalah Sesar Sintetik A (orde 1) terhadap Sesar Major A1 dan Sesar Major A2. Data alterasi yang mendukung hal ini adalah alterasi illitic yang memiliki orientasi yang sama dengan sesar sintetik orde 1. Berdasarkan data groundmagnet first horizontal derivative, terdapat anomali negatif pada urat Cikoneng-Cibitung yang menunjukkan bahwa pada daerah tersebut merupakan zona struktur dengan alterasi yang sangat intens (Gambar 21). 


\section{MAKALAH ILMIAH}
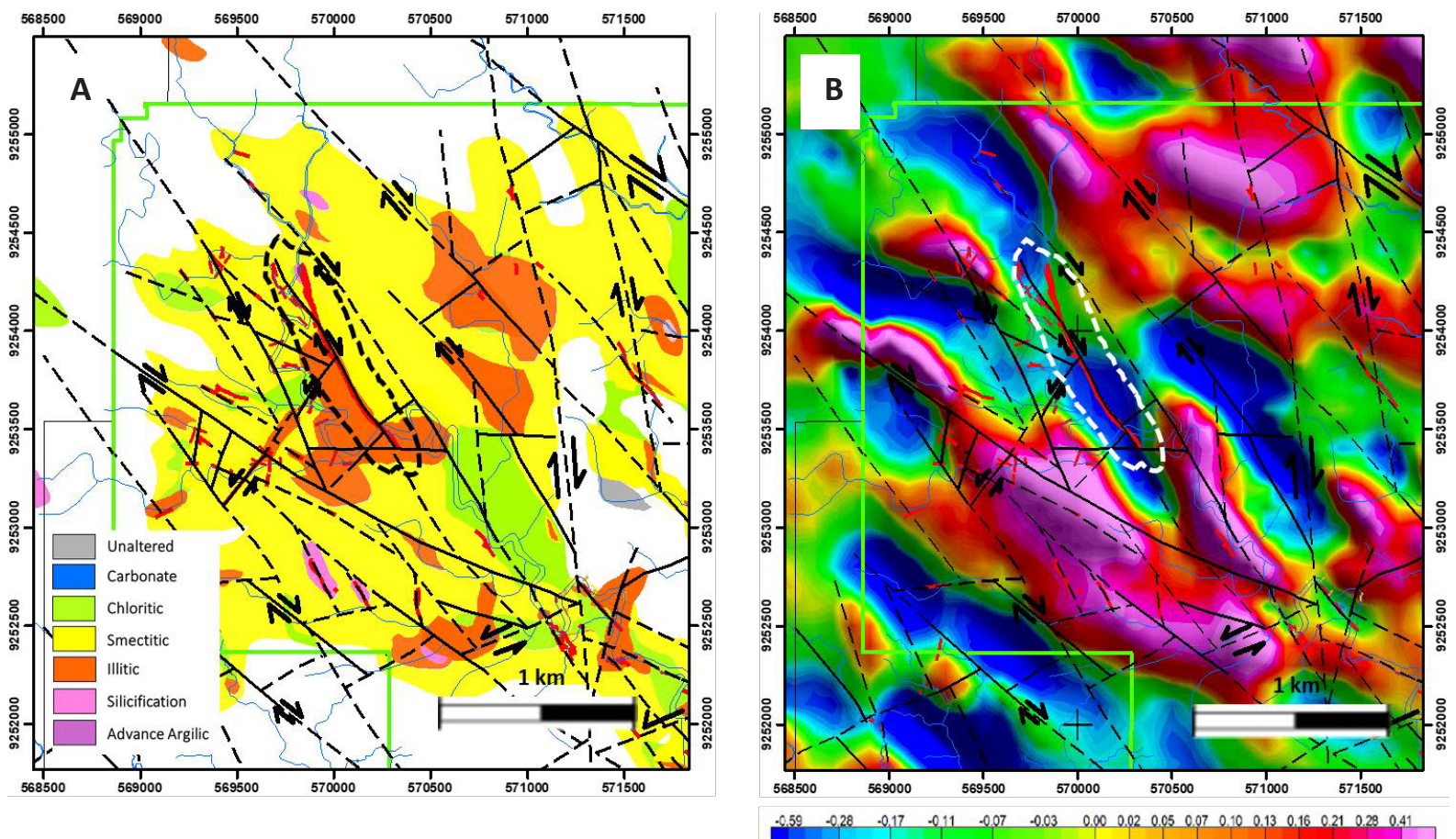

Gambar 21. Perbandingan peta alterasi dan struktur pada Urat Cikoneng-Cibitung (A) terhadap peta anomali groundmagnet first horizontal derivative (B)

Berdasarkan beberapa parameter di atas, didapatkan beberapa daerah rekomendasi untuk dilakukan eksplorasi lebih lanjut karena memiliki alterasi dan mineralisasi yang intens dan keberadaannya dikontrol oleh keberadaan struktur geologi yang saling berpotongan. Beberapa prospek tersebut digambarkan pada Gambar 21 yang juga didukung dengan data anomali groundmagnetic negatif seperti tertera pada Gambar 22.

\section{Prospek Cibengang}

Di prospek ini terdapat struktur sintetik (orde 1) yang didukung dengan alterasi illitic dan data groundmagnetic dengan anomali negatif. Lokasi yang berdekatan dengan Cikoneng - Cibitung dapat menjadikan prospek ini prioritas untuk dieksplorasi lebih lanjut. Anomali groundmagnet yang cukup luas dan mirip dengan anomali Cikoneng dan Cibitung memungkinkan prospek ini memiliki urat dengan tebal yang sama. Di daerah prospek ini terdapat struktur sintetik (orde 1) yang mengontrol terbentuknya Urat Ramada sebagai gash fracture. Pola alterasi di daerah ini berupa smectitic setempat hadir illitic. Didukung dengan anomali negatif groundmagnet yang cukup luas, daerah ini dapat menjadi prospek yang perlu dikaji lebih lanjut.

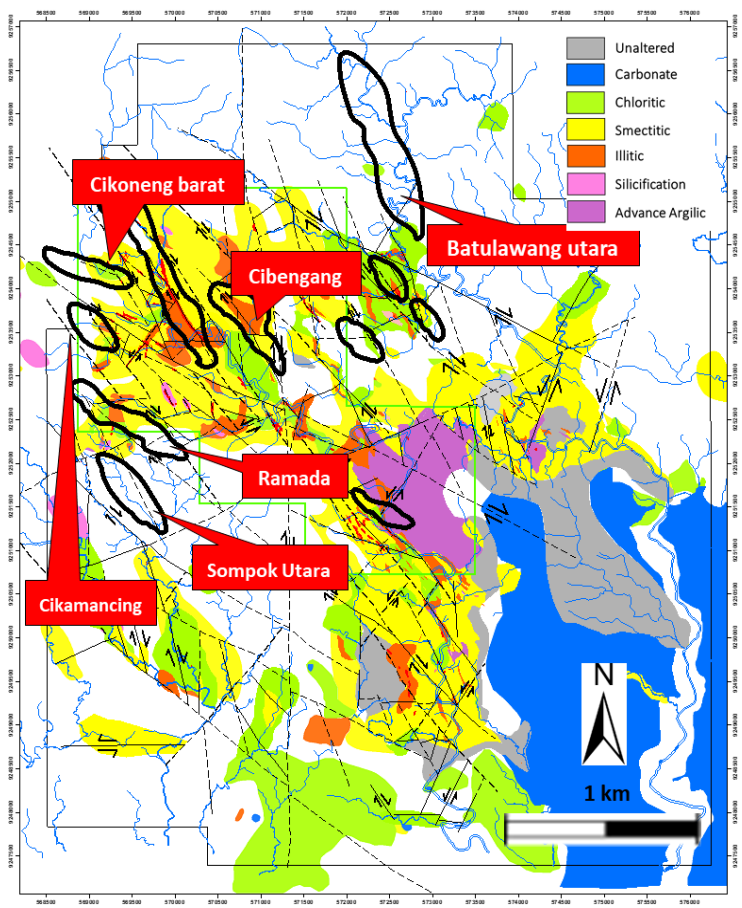

Gambar 22. Peta rekomendasi target eksplorasi yang di overlay dengan data struktur dan alterasi 


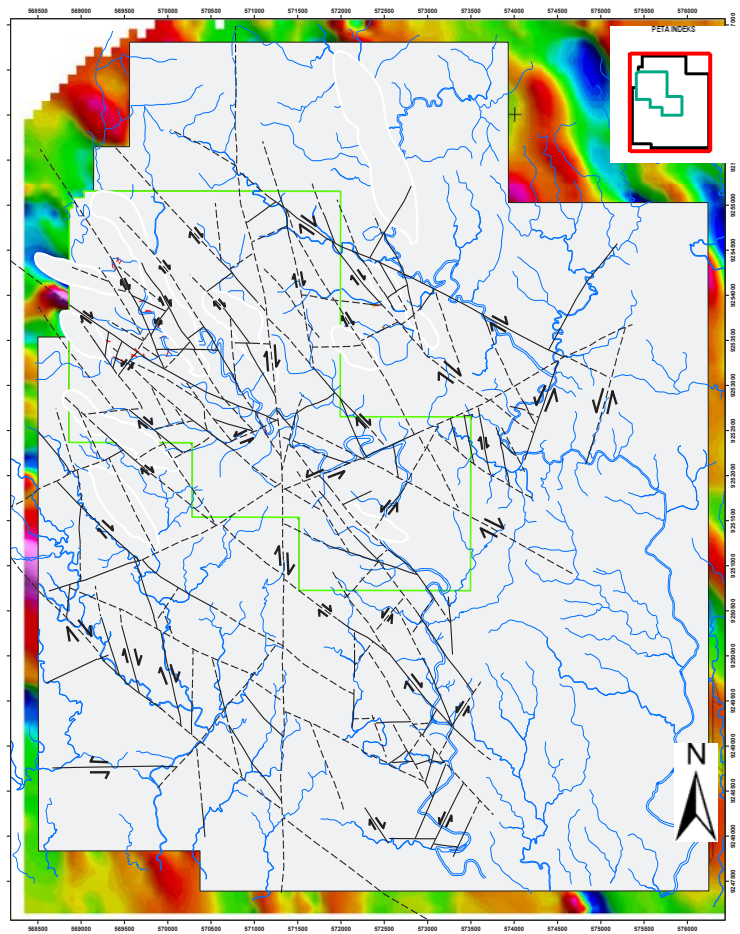

Gambar 23. Peta Anomali Groundmagnet Horizontal Derivative

\section{Prospek Cikoneng Barat}

Prospek ini juga perlu ditelusuri lebih lanjut karena memiliki anomali negatif groundmagnet yang cukup luas namun orientasi menunjukkan tidak searah dengan sesar bukaan sintetik A (orde 1)). Diintepretasikan bahwa anomali tersebut searah dengan Sesar Major A1. Prospek ini juga dekat dengan Urat CikonengCibitung sehingga dapat dipertimbangkan untuk dikaji lebih lanjut.

\section{Prospek Cikamancing}

Pada prospek teridentifikasi alterasi yang hadir adalah smectitic dan lubang penambang liar, Berdasarkan analisis struktur, pola anomali negatif groundmagnetic adalah gash fracture dari sesar Major A1, namun cukup sempit apabila dilihat dari luasan anomali.

\section{Prospek Sompok Utara}

Di prospek ini belum ditemukan adanya urat namun dari data lama dijumpai banyak float kuarsa dan setempat batuan andesit yang teralterasi intensif (kadar di atas $6 \mathrm{ppm} \mathrm{Au}$ ). Dilihat dari pola groundmagnet daerah Sompok ini menunjukkan anomali negatif yang cukup luas dan didukung dengan arah kelurusan yang diintepretasi adalah struktur sintetik A (orde 1).

\section{Prospek Batulawang Utara}

Berdasarkan pola groundmagnetic yang sangat luas di daerah ini serta orientasi yang sama dengan Sesar Sintetik A (orde 1) maka daerah ini dapat dijadikan target eksplorasi selanjutnya.

\section{Prospek Ramada}

Di prospek ini terdapat struktur sintetik (orde 1) yang mengontrol terbentuknya Urat Ramada sebagai gash dengan pola alterasi berupa smectitic setempat hadir illitic. Didukung dengan anomali negatif groundmagnet yang cukup luas, daerah ini dapat menjadi prospek yang perlu dikaji lebih lanjut.

\section{KESIMPULAN}

Berdasarkan hasil penelitian didapatkan korelasi yang baik antara persebaran struktur dengan alterasi. Persebaran struktur dapat menjadi acuan atau dasar penentuan zona mineralisasi maupun alterasi. Hal ini sangat penting terhadap tahapan eksplorasi endapan mineral.

Urat kuarsa hadir umumnya pada Sesar Sintetik A (orde 1 yang merupakan bukaan dari Sesar Major A, setempat juga hadir urat yang mengisi sesar antitetik namun hanya hadir di bagian barat Urat Cikoneng dan Urat Cibitung. Jalur utama mineralisasi yang mengontrol keterdapatan urat adalah Sesar Major A1 dan Sesar Major A2 yang membentuk mekanisme simple shear. Bukaan utama merupakan sesar Sesar Sintetik A (orde1) yang hadir di sekitar Sesar Major A1. Terdapat Sesar Major B yang juga membentuk pola alterasi yang menggantikan pola alterasi sebelumnya namun belum ditemukan nilai $\mathrm{Au}$ yang signifikan pada mineralisasi yang dibawa oleh sesar ini.

Perbandingan potensi mineralisasi IUP PT CSD dan PT Antam diketahui oleh faktor utama pengontrol bukaan yaitu Sesar 
Major A1 dan Sesar Major A2. Bukaan bukaan akibat kedua struktur tersebut hadir dominan di sekitar IUP PT CSD. Pola bukaan di IUP PT Antam yang terbentuk akibat kedua struktur kurang signifikan namun masih hadir float dengan kadar Au hingga 8,28 ppm di Prospek Ciparay. Di IUP PT Antam juga terdapat sesar pengontrol alterasi yang menggantikan alterasi sebelumnya dan lebih asam terutama di daerah Bukit Breksi dan Rahong namun kadar $\mathrm{Au}$ belum ditemukan yang cukup signifikan. Berdasarkan analisis struktur, pola alterasi dan data groundmagnetic terdapat beberapa daerah prospek yang perlu dilakukan eksplorasi lanjutan antara lain Prospek Cibengang, Prospek Ramada, Prospek Cikoneng Barat, Prospek Cikamancing, Prospek Sompok Utara, dan Prospek Batulawang Utara.

\section{UCAPAN TERIMA KASIH}

Penulis mengucapkan terimakasih kepada Tim Eksplorasi Emas Antam di Cibaliung, Manajemen PT Cibaliung Sumber Daya, dan Manajemen Unit Geomin \& TD PT Aneka Tambang Tbk yang telah mengizinkan penulis beserta tim melakukan kegiatan penelitian di wilayah IUP PT Aneka Tambang Tbk dan IUP PT Cibaliung Sumber Daya di Cibaliung, serta segenap dosen dan staf pengajar di Program Pasca Sarjana Fakultas Teknik Geologi Universitas Padjajaran yang telah mendukung dan membimbing penulis dalam membuat tulisan ilmiah ini.

\section{DAFTAR PUSTAKA}

Angeles, C.A., Prihatmoko, S., and Walker, J.S. (2002): Geology and Alteration-Mineralization

Characteristics of the Cibaliung Epithermal Gold Deposit, Banten, Indonesia. Resource Geology,52 (4), $329-339$.

Atmadja, R, S., dan Noeradi, D. (2006): Distribution of Early Tertiary volcanic rocks in south Sumatra and west Java, The Island Arc 14, 679 - 686.
Carlile, J.C. dan Mitchel. (1994): Magmatic arcs and associated gold and copper mineralization in Indonesia. Journal of Geochemical Exploration, 50, 91 $-142$.

Handayani, L., dan Harjono, H. (2008): Perkembangan Tektonik Daerah Busur Muka Selat Sunda dan Hubungannya dengan Zona Sesar Sumatera, Jurnal Riset Geologi dan Pertambangan, Jilid 18 No.2, 31 40.

Harding, T.P. (1985): Seismic Characteristics and Identification of Negative Flower Structures, Positive Flower Structures, and Positive Structural Inversion. Bulletin of the American Association of Petroleum Geologists, 69(4), $582-600$.

Harijoko, dkk. (2007): Characteristics of the Cibaliung Gold Deposit: Miocene Low-Sulfidation-Type Epithermal Gold Deposit in Western Java, Indonesia. Resource Geology Vol. 57 No.2, 114-123.

Hedenquist, J. W. (1996): Epithermal Gold Deposit: styles, characteristics, and Exploration. Resources Geology Special Publication Number 1.

Hilmi, F., dan Haryanto, I. (2008): Pola Struktur Regional Jawa Barat, Bulletin of Scientific Contribution, Vol 05 No 01, $57-66$.

Kurniawan, A., dkk. (2012): Internal Report Tim Eksplorasi Emas Unit Geomin, PT Antam Tbk.

Marcoux, E. and Milesi, J.P., (1994):Epithermal gold deposit in West Java, Indonesia: Geology, age and crustal source. In: van Leeuwen, T.M., Hedenquist, J.W., James, L.P., and Dow, J.A.S. (eds.), Indonesian mineral deposits: Discoveries of the past 25 years. Journal of Geochemical Exploration. 50, Amsterdam, p.393-408. DOI: 10.1016/0375-6742(94)90033-7

McClay, K.R. (1987): The Mapping of Geological Structure, London, 161 halaman. 


\section{MAKALAH ILMIAH}

Sudana, D. dan Santosa, S. (1992):

Geology of the Cikarang

Quadrangle, Java, Pusat Penelitian dan Pengembangan Geologi, Bandung, 13.

Usman, D.N., Sulaksana, N., Hirnawan, F., Haryanto, I., dan Bahri, N.S. (2017): Analisis Struktur Kekar Zona Mineralisasi Emas Miosen Akhir. Prosiding SNaPP2017 Sains dan Teknologi, Vol 7 No.2.

Usman, D.N., Sulaksana, N., Hirnawan, F., dan Haryanto, I. (2018): GoldSilver Mineralization in the NeoTectonism of Honje Formation and Cipacar Formation, in Cibaliung Block, Banten Province. Journal of Geoscience Engineering, Environment, and Technology, Vol 03 No 04.

$\begin{array}{ll}\text { Diterima } & : 26 \text { Juni } 2020 \\ \text { Direvisi } & : 6 \text { Juli } 2020 \\ \text { Disetujui } & : 23 \text { Agustus } 2020\end{array}$

